\title{
A participatory student workshop on climate change and sustainability: A comparative case study
}

Carole Larose ( $\nabla$ carole.larose@ens-lyon.fr )

lycée Corneille https://orcid.org/0000-0003-0818-2200

Eleanor Burke

Lincoln-Sudbury Regional High School

Christine Blaisot

Ecole Edouard Herriot

\section{Case Report}

Keywords: Experiential learning, participatory workshop, climate change, cross-age collaboration, youth sustainability activism

Posted Date: July 20th, 2021

DOI: https://doi.org/10.21203/rs.3.rs-707135/v1

License: (c) (i) This work is licensed under a Creative Commons Attribution 4.0 International License.

Read Full License 


\section{Abstract}

Climate change is an environmental and existential issue of great urgency, especially for today's youth. Until recently, the French national school curriculum had not given students much opportunity to learn about climate change (CC), its causes and repercussions, and mitigating measures to reach sustainable climate conditions. This article describes a six-week participatory, experiential workshop that brought together two groups of French students (one age 10 and the other age 16) to learn and teach each other about CC. Older students learned about the Conference of the Parties, COP21 Paris agreement and the IPCC climate findings and recommendations. Together the two groups developed greater understanding about $\mathrm{CC}$, and proposed concrete environmental actions that they could undertake at home and in their local district to reduce greenhouse gas (GHG) emissions. We examine four products of their collaboration:

- slide presentations that they created jointly,

students' written reflections on learning about sustainability and CC,

the group's list of proposed personal and family actions to decrease their carbon footprint, and

notes from a meeting with local governmental officials.

We draw inferences from these sources, and extract two recurrent themes in the students' learning. These themes highlight a mismatch between youth's sense of urgency to respond to the climate emergency and the older generation's sluggish pace of addressing it. This article is a qualitative case study of a successful attempt to raise students' awareness of sustainability and climatic issues, and to involve them in thinking collaboratively with others about the tasks ahead to address the problem of climate change from a local perspective.

\section{Introduction}

"Today's children will likely confront challenges we can hardly begin to imagine in a radically altered, unrecognizable world. Can we responsibly continue preparing them for business as usual? And if not, what can we do to make them ready for a survival game in which wild cards rule?"

-Dianne Dumanoski [1]

In 2015, before sustainability became embedded in the French curriculum, the co-authors of this article believed, like Diane Dumanoski, that today's children must be prepared for the radically altered world that they stand to inherit. We (Larose and Blaisot) designed an experiential workshop to introduce the basics of sustainability and sustainable development to our students through the lens of climate change. This article will describe and analyze the students' learning from the workshop. 
Currently, sustainability education is required to be present in both the French primary (école) and secondary school (lycée) curricula; its presence was reinforced in 2019 by the national curriculum agency: Conseil supérieur des programmes [2]. The initiative is called E3D, which stands for École/ Établissement en Démarche de Développement Durable (School Moving Towards Sustainable Development). Through this initiative, every staff member and student in each school building would play a part in the process of implementing concrete solutions in line with the United Nations' (UN) Sustainable Development Goals (SDGs) [줄 in the areas pertaining to school and facility management, such as energy and water usage, waste reduction, recycling and disposal, landscaping, and throughout all levels of classroom lessons. This vision has not yet been fully achieved.

High school teachers are more constrained to a specific curriculum (which currently does not include content on sustainability) in order to prepare students for their level exams. For this reason, our students who chose to take this optional project in Première (age 15-16, equivalent to US junior year), spent an extra hour of learning outside the normal school day for the 6-week duration of the course.

This article describes a six-week collaborative experiential workshop that brought together two groups of French students, (age 10 and ages 15-16) to learn and teach each other about climate change (CC). The older students learned about the Conference of the Parties (COP21) Paris agreement and the Intergovernmental Panel on Climate Change (IPCC) climate findings and recommendations. Together the two groups developed greater understanding about $\mathrm{CC}$ and proposed concrete environmental actions that they could take to their families and their local communities in order to promote climate sustainability. This collaboration was one of four award-winning curriculum projects in the field of sustainable development at the Concours des clés au développement durable (Contest of keys to SD) during France Climate Week in 2015. The award was presented by the Minister of Education, Najat Vallaud Belkasem.

Co-authors Larose and Blaisot undertook this project with their students in 2015, before the national sustainability curriculum was instituted; it occurred at a time when the topic of sustainability became prominent in the news media because of the UN-SDGs [3] and the UN Climate Change Conference, (The 21st Conference of Parties, or COP 21) held in Paris in November-December 2015. This is one reason why the authors chose to create this particular workshop. It is likely that students were also hearing the news and developed interest in registering for this workshop.

In this article we distinguish between the two age groups by referring to the older learners as 'students' and to the younger learners as 'pupils'. While the two age groups were at very different developmental levels, their performance in this collaborative project would allow them to learn from and with each other, and gain crucial 21 st century sustainability literacy skills such as:

- Gaining fundamental knowledge about environmental sciences: Many articles are featured by newspapers, television and other social media on issues of sustainability and climate change, but the notions and the terminology remain hazy in the minds of many people. 
- The ability to assess different kinds and sources of information: Students used scientific approaches to learn how scientists study climate change and make projections into the future, and learned that the models have to take into account many parameters and uncertainties. Climate skeptics use these uncertainties to argue that we are not in a drastic situation. Students learned to rebut such skeptics' arguments.

- Learning about responsible, realistic and hopeful behaviors: Students learned and in turn taught their parents about sustainability and climate change, without succumbing to catastrophic-thinking.

\section{Research Question}

Our research question was: How can we engage our students and pupils in a learning experience that will make them aware of the challenges of sustainability in our society? What are effective ways of involving them in sustainability issues?

In the Methods section, we describe our six-week experiential workshop that engaged the two groups to learn about sustainability together; we used four of their work-products to assess what they learned and gain insight into how aspects of the workshop promoted their learning. In the Results section we describe these student-pupil work-products:

- Informative slide presentations illustrating the learning that they had acquired,

- Written reflections on their learning,

- A list of personal and family actions for sustainable living, and

- Notes from the students' 2-hour meeting with a town official.

In the Discussion section we discern two themes that emerged from these student-pupil work products and we draw some inferences about their learning during these experiences. These observations and remarks will be of a qualitative nature because of the real-world setting and ungraded nature of our project. As this was a curricular project of an experiential nature for students, pupils and teachers together, the learners are not considered 'subjects' of a study, and no special permissions or board reviews were necessary. In the interests of confidentiality, no student is identified by name here; likewise for the town officials whom the students interviewed as part of the project.

\section{Methods}

Climate change (CC) is one of the biggest challenges of our times and is one of the UN sustainable development goals (SDGs) [3] to transform our world; SDG13 is dedicated to Climate Action. In addition, the climate ramifications of GHG emissions feature in several other SDGs, such as SDG2 zero hunger, SDG3 good health, SDG6 fresh water availability, SDG7 energy efficiency, SDG11 sustainable cities, and SDG16 peace and (climate) justice. In fact, many argue that the climate is at the core of all 17 goals, since it provides the habitable living spaces and food resources we need for survival. In the French high school curriculum, climate change is only taught during the last year, and only when students choose the 
specialty 'Biology and Earth Sciences'. In the absence of formal curriculum content, Larose conceived this project because she believes it is crucial that students get involved in this topic earlier in their learning, regardless of their academic studies and specialties. Co-author Blaisot, a teacher in primary school, was equally interested in early learning about sustainability, and both authors decided to organize a 6-week experiential learning collaboration between the two groups of learners.

Eight students and 27 pupils attended the workshop, hoping to gain scientific knowledge about CC. Furthermore, they wanted to understand the COP21 commitments that they were hearing about in the French news. This agreement of 197 negotiating parties marked the first time that a comprehensive universal agreement was reached in the fight against $\mathrm{CC}$. The French president called on the entire world to transform the Paris Accord on Climate into actions to confront this urgent problem. [4]

The two age groups worked independently in their separate schools for the first three weeks, to prepare for the joint-sessions with each other to occur in the last three weeks. The primary school curriculum system offered the advantage of being able to work on the project for entire days rather than only one hour per week. As this was a multi-disciplinary project, students and pupils were able to draw on a wide range of disciplines as they delved into learning about climate change and sustainable behaviors.

Table 1 describes the learning experience each group had during each of the 6 weeks. 


\begin{tabular}{|c|c|c|}
\hline wk & Students' learning experiences & Pupils' learning experiences \\
\hline 1 & $\begin{array}{l}\text { The students did not understand the } \\
\text { difference between weather and } \\
\text { climate. They learned to use weather } \\
\text { measurement instruments at the school } \\
\text { to learn weather data collection skills, } \\
\text { to read data records, and to use the } \\
\text { data to make graphs using their } \\
\text { collected data. From this they began to } \\
\text { see how weather and climate are } \\
\text { related but not the same. }\end{array}$ & $\begin{array}{l}\text { The entry point into the project for the pupils } \\
\text { was a study of weather from the perspective } \\
\text { of temperature. As a geography lesson, the } \\
\text { students learned about world climate zones; } \\
\text { in science class they conducted experiments } \\
\text { to learn what could cause air temperature to } \\
\text { vary in containers of different shapes, colors, } \\
\text { and materials; in technology class, they } \\
\text { created their own thermometers, } \\
\text { anemometers and rain gauges. In maths } \\
\text { class they plotted temperature data and } \\
\text { created graphs. }\end{array}$ \\
\hline 2 & $\begin{array}{l}\text { Students practiced online research } \\
\text { skills to learn possible climate } \\
\text { scenarios developed by the IPCC. They } \\
\text { researched data to understand } \\
\text { predicted temperature and precipitation } \\
\text { models in France, as simulated under } \\
\text { various CO2 emission levels. [ㅁ] ] In } \\
\text { addition they learned about the SDGs } \\
\text { established in } 2015 \text { by the UN and } \\
\text { reflected on how several of these relate } \\
\text { to climate change. [ㅁ] }]\end{array}$ & $\begin{array}{l}\text { To approach the theme of climate, the } \\
\text { pupils began with news articles about floods, } \\
\text { record temperatures and draughts in France. } \\
\text { Next they looked for the causes of these } \\
\text { events using documents that the two } \\
\text { teachers had chosen. Then they tried to find } \\
\text { other articles about other consequences of } \\
\text { CC beyond the ones they had read about in } \\
\text { the news articles. }\end{array}$ \\
\hline 3 & $\begin{array}{l}\text { After having learned about the causes } \\
\text { of climate change, the students wished } \\
\text { to explore its possible consequences } \\
\text { and propose solutions. Each student } \\
\text { created a slideshow to demonstrate }\end{array}$ & $\begin{array}{l}\text { In groups of three or four, the pupils } \\
\text { prepared a slideshow using the same seven } \\
\text { topics, focusing on the consequences of } \\
\text { global warming in France. This task was } \\
\text { more difficult for them because it was the }\end{array}$ \\
\hline
\end{tabular}




\begin{tabular}{|c|c|}
\hline $\begin{array}{l}\text { what (s)he learned and to propose } \\
\text { lifestyle changes that individuals can } \\
\text { make to work toward solutions. (Slide- } \\
\text { show topics included consumption, } \\
\text { agriculture, water resource } \\
\text { management, biodiversity, population } \\
\text { movement, health and energy.) }\end{array}$ & $\begin{array}{l}\text { first time that they had used digital tools to } \\
\text { make slideshows. }\end{array}$ \\
\hline \multicolumn{2}{|c|}{$\begin{array}{l}\text { Meeting between students and pupils } \\
\text { Both age-groups' slideshows were used to create a final slide show on each topic. } \\
\text { Each group, consisting of a student and three or four pupils, presented their work to } \\
\text { the others. Afterward, they discussed and proposed solutions and questions for the } \\
\text { meeting scheduled the following week at the Town Hall. }\end{array}$} \\
\hline $\begin{array}{l}\text { Appointment at the Town Hall with an } \\
\text { agent in charge of environmental } \\
\text { policies. } \\
\text { (Summary of meeting is in Results } \\
\text { section; see Appendix } 1 \text { for complete } \\
\text { notes). } \\
\text { Four students were invited to the town } \\
\text { hall to discuss solutions to help mitigate } \\
\text { the effects of CC. }\end{array}$ & $\begin{array}{l}\text { The two pupils who were elected to the } \\
\text { Municipal Children's Council went to present } \\
\text { the project to a Town Hall official. They } \\
\text { explained that they wished they could eat } \\
\text { local fruits and vegetables at the school } \\
\text { cafeteria, and they wished that they could } \\
\text { ride their bikes safely (in separate bike } \\
\text { lanes) to school and in town, where the } \\
\text { roads are national routes with fast-moving } \\
\text { trucks and cars. }\end{array}$ \\
\hline \multicolumn{2}{|c|}{$\begin{array}{l}\text { Visit to a local museum exhibition on the Amazon forest. } \\
\text { The exhibition consisted of a series of juxtaposed photos to make the most faithful } \\
\text { reconstruction possible of the environment of this forest. The guide described why } \\
\text { forests, this one in particular, are important in the control of GHGs. He showed } \\
\text { incredible plants and animals and explained their interactions with the environment. } \\
\text { The learners participated together in thematic workshops on the equilibrium of the }\end{array}$} \\
\hline
\end{tabular}


Amazon rainforest ecosystem. The guides answered questions about the animals, plants and human-caused threats to the balance of the system.

Table 1. Weekly learning experiences of each group over the 6 week project

In November of the following year, the pupils who had been elected "Eco-delegates" by their classmates took part in the youth forum on climate with delegates from other primary, middle and high schools in the Rouen school region, a convention held at the Regional Authority Headquarters. They heard a keynote on the causes and consequences of CC. Then they took the floor to present their ideas for reducing GHG emissions and their impact on the planet. Following this, they took part in thematic workshops. After the convention the pupils took these ideas into the middle school where they presented their project to students in the level ahead of them.

\section{Results}

Neither group of students received traditional grades for their work during the workshop. However, to assess what students had learned from the project, the collaborating teachers used evidence from four types of student/pupil work:

- Student-pupil-created slide presentations that illustrated the knowledge that they had acquired;

- Written reflections on their learning;

- Preparations for and participation in a discussion with Mrs. $\mathrm{H}$ at the local Town Hall;

- Creation of two lists of sustainable-living actions, one for their parents and one to propose to the town authorities.

\section{1) Co-created slide shows}

During the third week of the workshop, the secondary students prepared for meeting the pupils the following week. Each student chose a topic from this list: Consumption, Agriculture, Water Management, Biodiversity, Population migrations within and across national borders, Health, Energy.

They used critical thinking to choose pictures, graphs and statistical figures among resources proposed by their teacher. They were to use these communication supports to explain the worldwide consequences of global warming. Each group of students chose supporting evidence, then showed and explained their choices to the others. The larger group debated and selected the best illustrative evidence, and organized their documents to create a single slideshow. 
Similarly at the primary school, the pupils did the same work. Three or four children per group prepared a slideshow using the same topics but concentrating on the more localized consequences of global warming in France. This task was more difficult for them because it was the first time that they had used digital tools to make slideshows. They learned to choose visuals that would illustrate their words, in order to engage their audience.

In week four, the two groups met together: five or six pupils worked with one student on their chosen topic, and both age-groups' slideshows were used to create a final presentation for each of the eight topics. The following figures (1-7) show sample illustrations that they selected for each of the eight topics. An explanation of their reasoning follows each figure.

The pupils chose these images to speak to the issue of greenhouse gas emission in livestock raising: The steak's journey from animal to plate helped them explain how food, or specifically meat- production is a source of greenhouse gas emissions. Meat consumption is increasing all over the world but its production requires a lot of energy. Populations are increasing and cereal production has to increase to feed humankind as well. However, arable land areas remain stable, and can no longer increase to meet the need.

The students chose this chart because it astonished them to learn that agriculture is accountable for large amounts of GHG emissions. They were taken aback to learn that most French crops would need to be moved from south to north (especially vineyards, an important crop in France), and that enteric fermentation (digestion of food by livestock and the resulting methane they emit) is a main cause of agricultural greenhouse gas emissions.

The pupils and the students learned that just $3 \%$ of Earth's water is freshwater and $70 \%$ of this is consumed for crop irrigation. They proved that meat production consumes more water than cereals, tying this with the observations made during the work on consumption. They also learned that since resources are unequally spread over the Earth, political tensions over water rights will increase.

The pupils opted to work on the topic of drinking water. The two images of a glacier show its rapid melting in one century. This photo was one they could quickly and easily understand. They also chose a map of France showing the state of groundwater resources and regional water tables. It helped them learn about rainwater flow issues. The final image they chose shows the quantities of water consumed in different daily uses. It allowed them to question their own water usage for things like flushing the toilet and washing the car.

The pupils chose to use this map of French vineyards because it isn't only about plants that grow in their own region. French vineyards characteristically grow south of the Loire River (light pink areas on map). If climate warming causes viticulture to move northward (green areas) into the students' region of Normandy, as the scenario map predicts, this would change the French countrysides, with the disappearance of vineyards where they currently exist (gray areas); this could cause an economic disruption affecting both the wine and tourism industries. The students used a similar map to show that 
other plants (oak and beech trees, e.g.) will likely disappear from their current habitat regions in northern France.

The students learned from these maps that global warming has a direct effect on biodiversity, and that current species can either: vanish, be forced to migrate, or benefit from the change and increase their areas of distribution at the risk of threatening the native species in the areas they overtake.

The students had not previously considered the huge impact of the rise in sea level on coastal populations, where one-fifth of the world's people live, threatened by rising seas and floods. They also learned that loss of coastal population centers, homes and livelihoods would be a disaster for the poorest populations, who would lose everything they had, without financial or skill resources to replace their losses.

The pupils were quite interested in the unit on health, and they found it difficult to choose which of the many illustrations of the effects of climate change on health they wanted to use in their presentation. They chose a map showing the appearance and spread of the tiger mosquito, a disease vector, into France. The map shows that climate warming in France is creating a suitable habitat for the mosquito, and thus for the appearance of illnesses formerly unknown in French metropolitan areas. They also chose a graph showing the relationship between the increase in temperatures and the number of deaths during heatwaves. The students added information on air pollution especially linked to the formation of tropospheric ozone and the consequences on respiratory diseases, risks of sunstroke, dehydration, and cancers.

The students chose this chart to show that fossil energy consumption increases due to the growth in the number of people on Earth, resultsing in more emissions of GHG. They also learned the amounts of GHG stemming from energy production and the sites of energy waste within a house. This illustration allowed them to reflect on ways to economize on energy usage in their daily lives.

\section{2) Student reflections on their workshop experience.}

The feedback that students provided demonstrated their interest in this topic and indicated which skills they felt the project had encouraged them to develop. Table 2 presents direct quotes from students in both age groups. These quotes highlight their reflections on their learning.

Table 2. Sample learning reflections from both groups of students.

[The texts were originally in French and have been translated. Copies in the original French available on request from authors.] 


\section{Reflections of the high school students}

C. wrote: I think that understanding the climate is especially important because it's a major factor of our present and our future. If we want to find lasting solutions, and we want youths to mobilize rapidly and effectively, in my opinion it's useful to give them at least a minimum understanding of the climate. We can't swing into action and have an effect on a problem about which we don't really understand the causes. So, the climate is a truly necessary topic to learn in our curriculum.

$\mathrm{J}$ : We should focus on the origin and consequences of the greenhouse effect on the climate, especially effects such as loss of biodiversity. Too few people understand how one or two degrees $\mathrm{C}$ impacts biodiversity.

E: It was very interesting to investigate the solutions suggested in the COP21 agreement for slowing down climate warming, and to better understand future life-choices, like what individual daily actions would be beneficial in (partly) preserving biodiversity.

L: The meeting with the primary students was amazing; they had prepared a collection of materials and they already knew a lot [about CC]. They were very invested in finding solutions for global warming.

A: When we learn about sustainable development and climate, we aren't only learning from books. We also work at the same time with French, math, history, geography, and the sciences applied to real life. We think about the past and the future. We meet people outside of school and discuss climate issues. They take us seriously.

L: We learned that we have to act fast because if we wait to take action on the problem of climate change, it will be too late. Kids should explain to their parents that we have to change our habits, use the car less, and not buy products that aren't locally made.

$\mathrm{H}$ : Working on this project didn't feel like work because we went outside of the school, met people, and we worked on a subject we hear talked about on television which concerns us all. 
M: It was great going to work with the high schoolers, because we saw that we're all interested in the issues of CC. They also had more material, and that helped us understand it better.

\section{3) The list of lifestyle changes created by the students}

The pupils had strong ideas about solutions to reduce the amount of greenhouse gases. We worked on two axes: what children could do at their level and what adults should do at their level. For the younger learners, it seemed simple: they reasoned that if we know the solution to the problem, we apply it. They have not yet grasped the economic complexities or international negotiations that this can generate. Some of their proposals were not easily practicable, such as:

-Vehicles that consume fossil fuel must be banned immediately and replaced by biofuel or electric vehicles.

-We have to eliminate power plants that generate energy from fossil fuels and just use renewable energy sources.

Through discussion, the two age groups co-created a list of feasible activities they could employ and suggest in their meetings with town officials. Table 3 summarizes all the proposals the group discussed. 


\begin{tabular}{|c|c|c|}
\hline Students and Pupils & Parents & Town Hall \\
\hline Consumption & Consumption & Consumption \\
\hline Waste less & Waste less & At school cafeteria waste less food \\
\hline Eat less meat & Eat less meat & Eat less meat \\
\hline \multirow{7}{*}{$\begin{array}{l}\text { Consume local and } \\
\text { seasonal products }\end{array}$} & Consume local and & Consume local and seasonal products \\
\hline & seasonal products & Focus on sustainable food \\
\hline & Focus on sustainable food & Make compost with waste \\
\hline & Do not buy packaged & \\
\hline & products & \\
\hline & Prefer recycled products & \\
\hline & Make compost with waste & \\
\hline Water management & Water management & Water management \\
\hline Do not let the water & Only use drinking water & Collect rainwater for watering plants, \\
\hline run unnecessarily & when necessary & flushing toilets in public buildings \\
\hline \multirow{4}{*}{$\begin{array}{l}\text { Take showers } \\
\text { rather than baths }\end{array}$} & Collect rainwater for & \\
\hline & watering plants, flushing & \\
\hline & toilets, cleaning the car... & \\
\hline & Fix water leaks & \\
\hline Energy & Energy & Energy \\
\hline \multirow{3}{*}{$\begin{array}{l}\text { Turn off the lights } \\
\text { when leaving a } \\
\text { room }\end{array}$} & Do not leave electrical & Do not overheat public buildings \\
\hline & devices on standby & Thermally insulate public buildings \\
\hline & Buy low consumption & Prefer renewable energy \\
\hline Do not leave & devices & \\
\hline electrical devices on & Do not overheat homes & \\
\hline standby & Thermally insulate home & \\
\hline Close doors and & Prefer renewable energy & \\
\hline & & \\
\hline
\end{tabular}




\begin{tabular}{|c|c|c|}
\hline Transports & Transports & Transports \\
\hline Come on foot, by & Walk, bike, bus or & For the youngest students, organize \\
\hline bike or by bus to & carpooling to work & trips for several students on foot or by \\
\hline school & Buy only one car per & bike from their home to school \\
\hline Organize challenges & household, preferably an & (pédibus, vélobus-- French terms for \\
\hline at school to promote & electric car. & walking-pools or bike-pools) \\
\hline non-car travel & & \\
\hline Biodiversity & Biodiversity & Biodiversity \\
\hline Make a garden at & Plant non-invasive plants & Fill bins for green waste \\
\hline school & adapted to the local & Develop green spaces in the \\
\hline Set up a beehive at & climate & municipality \\
\hline \multirow[t]{4}{*}{ school } & & Do not use pesticides and insecticides \\
\hline & & Protect uncommon animals or plants \\
\hline & & species in our area (such as the \\
\hline & & violette de Rouen) \\
\hline
\end{tabular}

After presenting these proposals at Town Hall, the learners discussed their proposals with their families. Thus, parents decided to make some commitments.

Table 4 shows commitments made by each group, students, families, and local officials. Because the school year ended and students moved on to new settings, it was not possible to follow up on how well the family commitments were followed. The pollinator garden, however, was completed at the primary school the year just after the project, as seen in Figure 8.

Table 4. Commitments to behavioral change by each group: students, parents, town officials. 


\begin{tabular}{|c|c|c|c|}
\hline Topic & Students and pupils & Parents & Town hall \\
\hline Consumption & $\begin{array}{l}\text { - In both schools, pupils and students } \\
\text { organized to sort papers, plastic. Pieces of } \\
\text { paper could be used again or thrown into the } \\
\text { recycling bin. } \\
\text { - Get schools to purchase recycled materials } \\
\text { - In the school lunchroom, the pupils can } \\
\text { choose what they eat and they often take } \\
\text { more bread or fruit than they can finish. A } \\
\text { calibrated clear bin was created in the } \\
\text { lunchroom to illustrate the waste that could } \\
\text { be avoided with more careful choices. }\end{array}$ & $\begin{array}{l}\text { - Buy local } \\
\text { products } \\
\text { - Not buy } \\
\text { packaged } \\
\text { products for } \\
\text { snack time. }\end{array}$ & $\begin{array}{l}\text { - School } \\
\text { lunch: one } \\
\text { organic meal } \\
\text { once a week } \\
\text { and local } \\
\text { produce used } \\
\text { in all meal } \\
\text { preparation }\end{array}$ \\
\hline $\begin{array}{l}\text { Water } \\
\text { management }\end{array}$ & $\begin{array}{l}\text { Turn off water while brushing teeth } \\
\text { Take shorter showers }\end{array}$ & & $\begin{array}{l}\text { Push button } \\
\text { on taps in } \\
\text { schools }\end{array}$ \\
\hline Energy & $\begin{array}{l}\text { wear sweaters at home } \\
\text { Turn off lights when leaving room } \\
\text { Power down computers and electronics when } \\
\text { not using }\end{array}$ & $\begin{array}{l}\text { Give warm } \\
\text { clothes to the } \\
\text { pupils for } \\
\text { cooler } \\
\text { classrooms } \\
\text { Lower home } \\
\text { thermostat }\end{array}$ & $\begin{array}{l}\text { Lower the } \\
\text { temperature } \\
\text { in school } \\
\text { classrooms }\end{array}$ \\
\hline Transport & $\begin{array}{l}\text { Students take common transport or use their } \\
\text { bicycles. }\end{array}$ & $\begin{array}{l}\text { Ride bicycles } \\
\text { or walk or } \\
\text { carpool } \\
\text { daily } \\
\text { Teachers } \\
\text { made the }\end{array}$ & $\begin{array}{l}\text { Bike lanes } \\
\text { around } \\
\text { schools and } \\
\text { in newly } \\
\text { renovated } \\
\text { town areas. }\end{array}$ \\
\hline
\end{tabular}




\begin{tabular}{|c|c|c|c|}
\hline & & $\begin{array}{l}\text { same } \\
\text { commitments }\end{array}$ & $\begin{array}{l}\text { Build car- } \\
\text { parks to } \\
\text { allow people } \\
\text { to take bus } \\
\text { into town }\end{array}$ \\
\hline Biodiversity & $\begin{array}{l}\text { The next year, at primary school, flower } \\
\text { gardens were planted where bees could find } \\
\text { food and pollinate the other plants. }\end{array}$ & $\begin{array}{l}\text { Help with } \\
\text { gardening, } \\
\text { provide tools } \\
\text { and seeds } \\
\text { and plants. }\end{array}$ & $\begin{array}{l}\text { Town council } \\
\text { provided } \\
\text { bulbs and } \\
\text { seeds to } \\
\text { children for } \\
\text { their garden }\end{array}$ \\
\hline
\end{tabular}

\section{4) Conversation with an agent at the town hall.}

This meeting was organized between four students and an agent from the municipal sustainable development department. Students had prepared their questions, but time was too short to broach all the topics. Traffic circulation problems in town was the first topic of discussion. Students stated the case that more cycle lanes and pedestrian streets were needed in Rouen. In response, the agent told them that store-owners were in need of more parking spaces in front of their shops. However, she said that the city centre policy has changed, the parking duration is shorter and the price higher, to park cars. The number of buses is increasing, and rides were modified to respond to the needs of inhabitants. Students replied that the current rate is very expensive even for them and asked if city councilors would consider lowering rates. Her answer was that this subject would require examination. About urban travel, students suggested encouraging carpooling. The agent mentioned that the mayor pressured staff members to create carpools by setting up an intranet to communicate. Finally, students talked about soft modes of transport for the pupils between school and home. She replied that, "Some pedibuses are organized in partnership with the school, families and the town hall," and she added that she was aware that this was not enough without really proposing solutions.

Students raised a second topic: wastage at the school cafeteria. The agent explained that a young employee had been hired to investigate this subject; this answer seemed to satisfy the students.

They made a third suggestion: that the school could reduce its carbon footprint by serving a vegetarian lunch once a week. The students found the response disconcerting and frustrating: She told them, "Parents are not ready for that." (Contemporaneous notes from this meeting are in Additional file 1.) 
The pupils held a separate but similar meeting with another town official, with similar results. The conversations are analyzed in the discussion section.

\section{Discussion}

As we study and reflect on the evidence of the students' learning from this project, we have discerned two salient themes in their work. First, the collaboration was a crucial component of their learning; and second, they are compelled to take action in the struggle to limit climate change, and they are witnessing the utter failure of the adults' political systems to treat the problem as the emergency that it is.

\section{1) Meeting with and teaching kids of another age group was "wonderful."}

The students found the cross-age-group meeting wonderful* because they were amazed* by the pupils' spontaneity and by the depth of knowledge that the younger ones had already learned with their teacher. The pupils were very impressed by the size of the high school and a little intimidated by the older students; however, when the groups were formed, they quickly lost this shyness. *(One student described the first meeting as merveilleux.)

Everyone's attention was focused on their work. While organizing the final slide show they discussed amongst themselves without any need of adult input. After the presentations, the pupils and students created the list of lifestyle changes; this discussion, too, was very autonomous.

The students listened respectfully to suggestions from the pupils, who were glad because the older ones took their ideas seriously. In this situation, it seems that everybody was equal, every idea from each of them allowed the group to seek solutions. They had a unified goal: learning about climate change issues, sharing information and proposing solutions. They all shared the same convictions that society must mobilize against climate change.

The pupils became very aware that the problems of climate change concern everyone, and no matter what one's age, one can participate and act for the environment. They were able to exchange views with the students about the worldwide climate situation; although they worked mostly on French climate events and information, they could bring their broader understanding to it. They were also able to imagine their future selves because they could see that they would become students in just a few years.

Studies abound in the past 20 years' academic literature, showing that engaging home and family with students' learning at school increases the student's investment in their learning and their long term success in school. $[14, \underline{15}, \underline{16}]$ The conversation our students had with their parents about pro-climate actions they could take as a family is an example of the way that this project contributed to family engagement in student learning. The parents expressed amazement at the involvement of pupils and students to find solutions to mitigate the consequences of climate change.

\section{2) Young people feel an urgent need to address climate change-NOW.}


Their civic actions (2.1) led the students to a keen awareness that the slow pace of adults' willingness to make change is deepening the injustices caused by climate change (2.2), and is woefully insufficient (2.3) for the current crisis.

\subsection{Taking civic action}

As the students in this collaboration learned about the unsustainable nature of the accumulating repercussions of climate change, they developed a pressing desire to take civic action. As one student said, "This is our present and our future." Youths see that their own future, indeed the future of the world's population is here, now. There is no time to waste.

Both groups of our students decided to "think globally and act locally" by taking their proposals to two different town hall officials. In both cases, the government official listened sympathetically, then tried to explain that changes cannot happen overnight, and must go through channels of the political system. Here are sample responses to the student's requests:

- For lower bus fares: "The topic requires study."

- For bike lanes for safer passage to school: "The store-owners' desire more parking spaces, so bike lanes aren't easily created in town."

- For the city to encourage carpooling: "The mayor encourages it for town employees, but we recognize this is not enough."

- To address school lunchroom food waste: "A young person has been hired to investigate this subject."

- To the proposal to serve meatless lunch one day per week to reduce the school's carbon footprint: "Parents are not ready for that." [The students didn't challenge this assumption, but certainly could have.]

The pupils took their similar positions to a different town hall agent. They inquired about the possibility of getting bicycle trails established so they could ride their bikes to school safely. His response: "This is "under study-but it doesn't depend solely on the mayor's office/town hall government, and it is complicated to create bike paths where there had not been foresight to make a place for them when the roads were originally constructed."

The children did achieve two small victories in their attempts to influence local environmental policies. They wanted to raise awareness among their fellow students against food waste at the school lunchroom. This demand was granted, and the class delegates from now on can participate in school lunch planning groups in the school that take place every trimester. The pupils created an informative poster campaign to educate their peers.

Following the presentation of their project to the town hall agent, the pupil municipal councilors worked on installing pollinator gardens at school and around town, with the goal of promoting 
biodiversity. They also posted informative signs about beneficial insects that inhabit these municipal gardens.

\subsection{Youth sense of climate injustices}

All the students expressed a desire "to understand the causes and consequences of climate change in order to mobilize against it." By studying the causes of climate change, the youth learned that human activities have impacts on the environment. They understood that $\mathrm{CC}$ would affect not only their lives but also the lives of people in poorer countries, with even more disastrous consequences: desertification, depletion of water resources, salinization of soil, rising ocean levels.

They learned that the hardships of climate change are falling first upon regions where the people have few or no resources to struggle for survival through these impending crises. This knowledge raised their awareness of the world-leaders' failure to address climate change with any urgency for the sake of environmental justice and addressing human suffering. The students began to sense that they have a stronger moral compass than adult politicians, when it comes to speaking out for climate justice to ameliorate the suffering of the world's less resourced people.

In the last week of the project, the students visited an exhibition on the Amazon rainforest. Both the students and the pupils wondered, "Why should we worry about the Amazon rainforest?" At the exhibit they learned that the forest is an asset for the storage of greenhouse gases. Nevertheless, it is destroyed to plant crops and breed cattle, which both release yet more methane. As the children see it, "Everyone knows but nobody does anything." It is really difficult for young people to understand why adults do not take responsibility in the face of this disaster.

\subsection{Frustration with slow pace of adult leadership}

During one of the slide presentations, a pupil lamented, "The polar bears will disappear!" Young people feel deep emotional ties with animals in general, and charismatic animals like polar bears, pandas, and whales particularly evoke these feelings. The students learned that Earth is going through a sixth major biological extinction crisis. They know that during geological time there have already been large-scale extinctions which were due to natural causes. They also know that the species that survived these crises have diversified. However, they learned that this current crisis has anthropogenic causes and is occurring faster than past ones. Once again, they wonder why adults won't act swiftly and decisively to halt this extinction crisis.

As they learned about the world leaders' responses to climate change (or lack thereof), one of the students stated with dismay, "The Intergovernmental Panel on Climate Change was created at the end of 1988 and almost nothing has been done. We need more rapid change to respond to the urgency of climate change." They inquired, "Why did adults not react sooner and why are their actions still only moderate? Why is there a gap between what adults say and what they actually do?" Sylvie Granon, researcher at neurosciences institute in Paris-Saclay, who is co-writer of a chapter in the book "Le Souci 
de la nature" suggests the reason adults may be so slow to respond attributes blame to the human brain: "Le changement est extrêmement énergivore et stressant pour l'organisme, qui va essayer de diminuer l'impact de ce stress en adoptant les comportements les plus automatiques et les plus rassurants possible." (Translation: Change is extremely energy-consuming and stressful for organisms, which try to diminish the impact of this stress by adopting automatic habitual behaviors which serve to reassure as much as possible.)_[17] This is not meant to excuse the leaders' slow response, but merely as a possible explanation for it. The young generation is more clear-headed and realistic about the urgency of the problem than the adults who make the laws and affect their future.

The slow, politically motivated adult tactics in the face of what the students see as a blazing emergency frustrate young people wherever they try to sound an alarm to awaken adults to the problem, as seen in other articles in this collection (Luna and Mearman; Burke et al.) $[\underline{18}, \underline{19}]$ and around the world in youth climate movements $[\underline{20}, \underline{21}, \underline{22}, \underline{23}]$. As one young German activist states,

"What the world community is doing with the planet, will be described one day as the biggest political failure of our time." [21]

This aptly describes how our students felt after their encounters with adults in charge at the municipal level, and after studying about the painfully slow processes of change as world leaders quibble over details of climate agreements. And it has been laid at the young people's doorstep. Their generation did not cause the problems but in their adult lifetimes the bill is coming due for the neglect of the preceding ones. A political failure, indeed; and an economic and humanitarian disaster of global proportions are the burdens today's youth, as tomorrow's leaders, will have to confront.

\section{Conclusion}

The aim of this collaborative learning project was to engage our students in a learning experience that would make them aware of the challenges of sustainability in our society. We hoped to create an effective way to involve them in sustainability issues at a personal and local level. At the end of this workshop, the students learned that the greenhouse effect is a natural phenomenon but that the increase in greenhouse gases is anthropogenic, or human-caused. From the youngest to the oldest, they understood why a mobilization from simple citizens to elected representatives is necessary, in order to reduce our greenhouse gas emissions and find mitigated responses to reduce the consequences of the change already underway.

The solutions proposed by the students of this workshop were to show how each person at their level of skills can have a positive influence on the problem of climate change. Our students judged that the decisions made by adults regarding these problems were not equal to the high stakes for our planet. 
Two strong themes emerged from student work products: (1) The collaboration of two age groups proved to be more than the sum of its parts; (2) Unnerved by the slow response from the adult world of politics, the students felt compelled to take immediate personal and civic action to confront climate change.

Cross-age and cross disciplinary collaborations such as this are not easily created in public schools. Sustainable issues are now appearing in the French curriculum at different levels at school, and beginning to involve non-teaching staff, as well (e.g. food services, facilities managers). In primary school, a single classroom teacher teaches all subject matters to the pupils. In secondary schools, any teacher could teach climate change; however, it is mainly science and social studies teachers who incorporate climate curriculum in their courses.

Furthermore, teachers who teach these topics rarely consult each other. Many say that they have no time to collaborate and organize a multi-disciplinary project with their students, although a multitude of studies have shown that cross-disciplinary teaching is an excellent way to create a better learning situation for students; all their lessons are connected and they can understand the real-life links among all the subject areas. [24] The boundaries between "biology" and "math" and "language arts" evaporate, and learners can create a meaningful schema of how the world functions as an ecosystem.

The project's significance lies in the students' ability to make proposals to mobilize the attention of their classmates, their teachers, their parents and adults in general. The teacher's role is, of course, to allow students to develop knowledge to understand climate change and also to support the various actions often implemented by students to do their part in mitigating its consequences.

This is just one small example of the growth that occurred when two groups of students came together to share their learning about sustainability and take action to confront climate change. The themes we heard in the students' work products represent only their own experience, but we draw parallels to the voices of other young people the world over who are crying out with the same voice.

One main area for future development is the training of teachers. Even though they have the resources to teach sustainable development issues, many do not feel ready to teach this topic. Teachers may think that teaching sustainable issues is difficult because the content of the curriculum is not clearly identified. They feel that these topics are not the priority for students because no graduation assessments (national exams) in this field exist.

If sustainability is to be part of the school curriculum, pre-service educator training must include skill development in teaching about sustainability in and across subject area 'silos'. In-service professional development is needed for mid-career teachers, to provide a scientific refresher as well as workshops to model project ideas. School administrators must design schedules with common meeting times so teachers can successfully design integrated projects across disciplines; such collaborations will serve to break down the false disciplinary boundaries and to reduce teachers' fears about designing new curricular lessons. The conclusion must be optimistic; everyone is now aware of the urgency to take actions to mitigate the consequences of global warming. Even though actions are currently insufficient, 
the world's youth urge adults to take responsibility; the temperature is rising, and the increasing frequency of "100-year storms," glacial-melt floods, arctic jetstream wobbling, wildfires, and droughts all indicate that climate instability has reached crisis level. The faster and stronger we respond, the better for all the world's creatures.

\section{Declarations}

\section{Ethics approval and consent to participate}

Not applicable. No research was conducted, thus no ethics approval or consent to participate was needed.

\section{Consent for publication}

The three authors of this manuscript give consent to publish it in the Sustainable Earth special issue.

\section{Availability of data and material}

No data was collected during this journey in civic participation. All relevant materials are included in this article, or as additional files.

\section{Competing interests}

Not applicable.

\section{Funding}

Not applicable. This was a public school curricular and extracurricular experience.

\section{Authors' contributions}

The co-authors each contributed sections to the account: CL contributed information pertaining to the students' experiences and work products; CB contributed information about the pupils' experiences and work products; EB contributed organizational suggestions and English language translations; all three authors contributed to thematic analysis of the results.

\section{Acknowledgements}

The authors are grateful to the pupils and students who participated in this project.

We thank our inspectors for their listening and support as well as their involvement in sustainable issues: Patrice Favier and Jean-Marc Bellamy. We are also thankful to the ministry of national education in France which awarded this project at the Concours des clés au développement durable during France Climate Week in 2015. It was presented by the Minister of Education, Najat Vallaud Belkasem. 
We also offer gratitude to the staff at IFE in Lyon who are involved in the project "tremplin pour l'enseignement des sciences: climat et météo": Charles-Henri Eyraud, Eric Le Jan, Gérard Vidal.

We also wish to thank the members of the Sustainable Earth guest editorial board who offered feedback on earlier drafts of the manuscript, especially David Crookall, Gillian Bowser, and Jaimie Cloud.

\section{Authors' Information}

Carole Larose : Biology and Geology Teacher in a high school (lycée Corneille in Rouen), teacher-trainer in Académie de Rouen; partner-teacher at IFE-ENS-Lyon (Institut Français de l'Education, Ecole Normale Supérieure de Lyon) for the project "Tremplin pour l'enseignement des sciences: climat et météo." (Springboard for science teaching: climate and weather.)

Christine Blaisot: primary school teacher (École Edouard Herriot Le Mesnil-Esnard); Teacher-trainer especially in Sciences. Membre de l'IREM (Institut de Recherche dans l'Enseignement des Mathématiques) de Rouen

Eleanor Burke: Lincoln-Sudbury High School Associate Principal, Retired (2017); MA Sustainability and Environmental Management, Harvard University Extension; M.Ed. Bilingual Education, Antioch University; BA. Spanish and Psychology, Duke University, Durham, NC

\section{References}

[1] Dumanoski, D. The End of the Long Summer: Why we must remake our civilization to survive on a volatile Earth. Three Rivers Press, Random House, NY 2009.

[2] Conseil supérieur des programmes (2019)

Renforcement des enseignements relatifs au changement climatique, à la biodiversité et au développement durable dans les programmes de la scolarité obligatoire

[3] United Nations Sustainable Development Goals

(2015) https://www.un.org/sustainabledevelopment/sustainable-development-goals/

[4] Gouvernement.fr COP21 : signature de l'Accord de Paris

“Le président de la République a appelé le monde entier à traduire l'Accord de Paris sur le climat, adopté en décembre lors de la COP 21, "en actes" pour faire face à l'urgence. 
[5] Ministère de la transition écologique et solidaire: Drias-les futurs du climat. http://www.driasclimat.fr/ Accessed 2015.

[6] United Nations Sustainable Development Goals (Objectifs de Développement Durable) 2015 United Nations Sustainable Development - 17 Goals to Transform Our World https://www.un.org/sustainabledevelopment/fr/objectifs-de-developpement-durable/

[7] Source: extrait d'une brochure "Des gaz à effet de serre dans mon assiette" publiée par Réseau action climat France (itinéraire d'un steak haché et émissions de GES)

(Publisher gives permission to use these in public education.)

[8] http://www.reporterre.net/climat-l-agriculture-est-la-source

[9] Ministère de la transition écologique. https://ecologie.gouv.fr/404

https://ecologie.gouv.fr/sites/default/files/ONERC_FichesIndicateur_glacier.pdf

[10] Source: kit pédagogique le changement climatique p36

https://reseauactionclimat.org/publications/kit-pedagogique-changements-climatiques/

(Publisher gives permission to use these in French public education.)

Original source: Proceedings of the National Academy of Sciences of the USA. http://www.pnas.org/content/early/2013/04/03/1210127110

[11] Source: Kit pédagogique le changement climatique $p 30$

https://reseauactionclimat.org/publications/kit-pedagogique-changements-climatiques/ 
[12] Source: Kit pédagogique le changement climatique p 40

https://reseauactionclimat.org/publications/kit-pedagogique-changements-climatiques/

[13] Source: Grubler, A et al. (2012); Chapter 1: Energy primer. In: Global Energy Assessment: Toward a Sustainable Future. Eds. Team, GEA Writing, pp.99-150 (October 2012): Cambridge University Press and IIASA. http://pure.iiasa.ac.at/id/eprint/10068/

Used in accord with https://creativecommons.org/licenses/by/3.0/

[14] Punter R.A., Glas C.A.W., Meelissen M.R.M. (2016) Literature Review. In: Psychometric Framework for Modeling Parental Involvement and Reading Literacy. IEA Research for Education (A Series of In-depth Analyses Based on Data of the International Association for the Evaluation of Educational Achievement (IEA)), vol 1. Springer, Cham. https://doi.org/10.1007/978-3-319-28064-6_2

[15] S. Wilder (2014) Effects of parental involvement on academic achievement: a meta-synthesis, Educational Review, 66:3, 377-397, DOI: 10.1080/00131911.2013.780009

[16] Youssef Tazouti. École-famille-communauté; Des pratiques de collaboration efficaces. La revue internationale de l'éducation familiale 2014/2 ( $\left.n^{\circ} 36\right)$.

[17] Fleury, C. and Prévot, A-C. Le souci de la nature: apprendre, inventer, gouverner. Paris, CNRS (Centre national de la recherche scientifique) éditions. (2017)

[18] Luna and Mearman, "Learning to Rebel." Sustainable Earth 2020 3:4 https://www.biomedcentral.com/collections/ls

[19] Burke et al, Teen activism leads to local laws banning single-use plastics: a two-year experiential learning journey. Sustainable Earth 2020 3:15 https://doi.org/10.1186/s42055-020-00035-0 
[20] Marris, Emma. Why young climate activists have captured the world's attention. Nature international journal of science, news article, 18 September 2019. https://www.nature.com/articles/d41586-01902696-0 Accessed 15 August, 2020.

[21] Schnaidt, Isabel and Inma Galvez-Shorts, Earthday.org. 14 June 2019. https://www.earthday.org/2019/06/14/15-youth-climate-activists-you-should-be-following-onsocial-media/_Accessed 15 August, 2020.

[22] Turns, Anna. Meet generation Greta: young climate activists around the world. The Guardian. 28 June 2019 . https://www.theguardian.com/environment/2019/jun/28/generation-greta-young-climateactivists-around-world Accessed August, 2020.

[23] Unigwe, Chika. "It's not just Greta Thunberg: why are we ignoring the developing world's aspiring activists?" The Guardian, 5 October 2019. https://www.theguardian.com/commentisfree/2019/oct/05/greta-thunberg-developing-worldactivists Accessed August 2020.

[24] Peters-Burton, E. E. \& Holincheck, N. (2020). Interdisciplinary curriculum and integrated instruction: A literature review. New Tech Network, Napa, CA. https://32dkl02ezpk0qcqvqmlx19lk-wpengine.netdnassl.com/wp-content/uploads/2020/11/Interdisciplinary-Curriculum-and-Integrated-Instruction-ALiterature-Review-2020.pdf Accessed February 2020

\section{Figures}




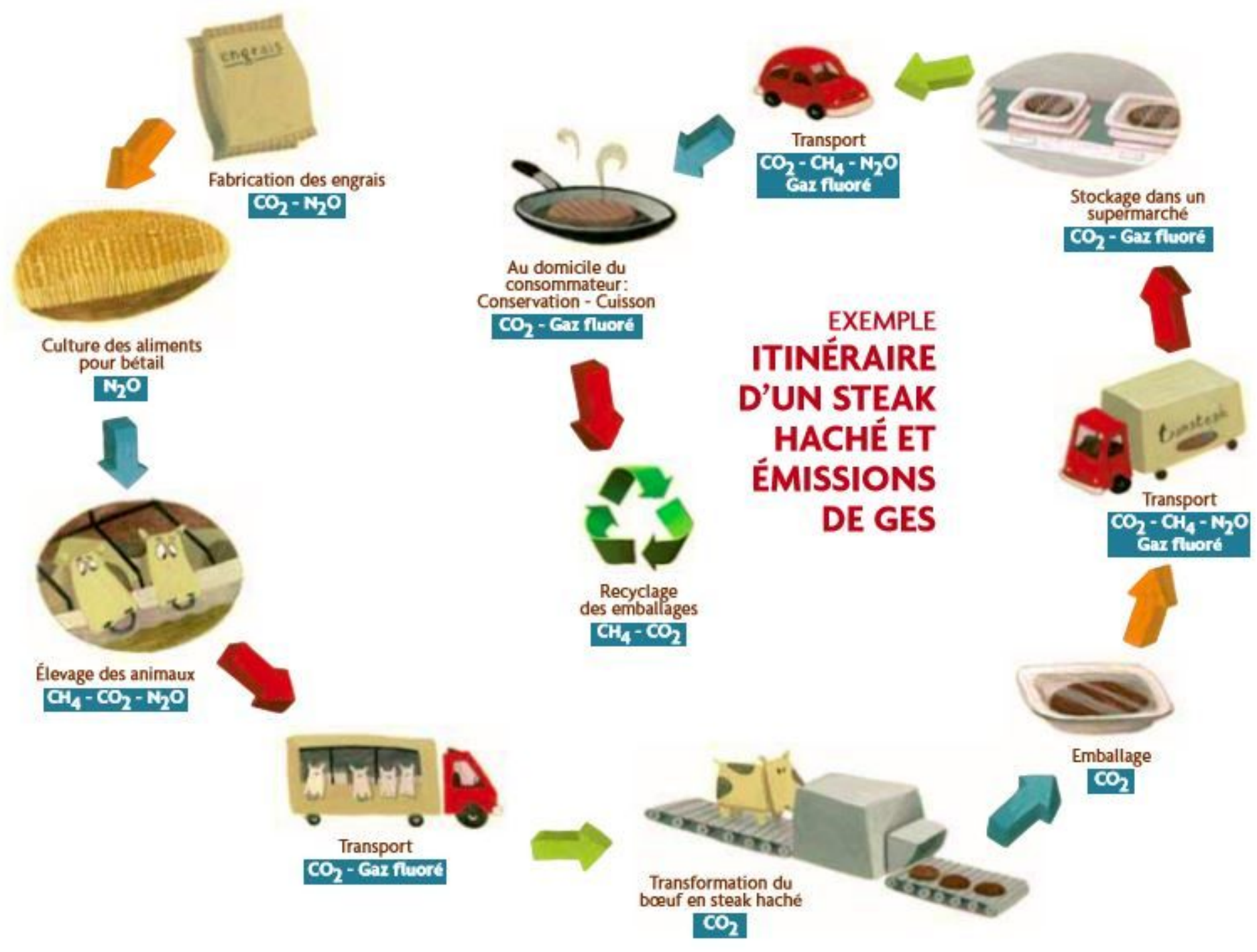

Figure 1

Representative slide from a student presentation about Consumption and climate change. Credit : extrait d'une brochure "Des gaz à effet de serre dans mon assiette" publiée par Réseau action climat France (itinéraire d'un steak haché et émissions de GES) 


\section{Évolution des émissions agricoles}

Évolution des émissions agricoles sur chaque continent, entre 1990 et 2012, en Gigagrammes équivalent CO2

2459027,871

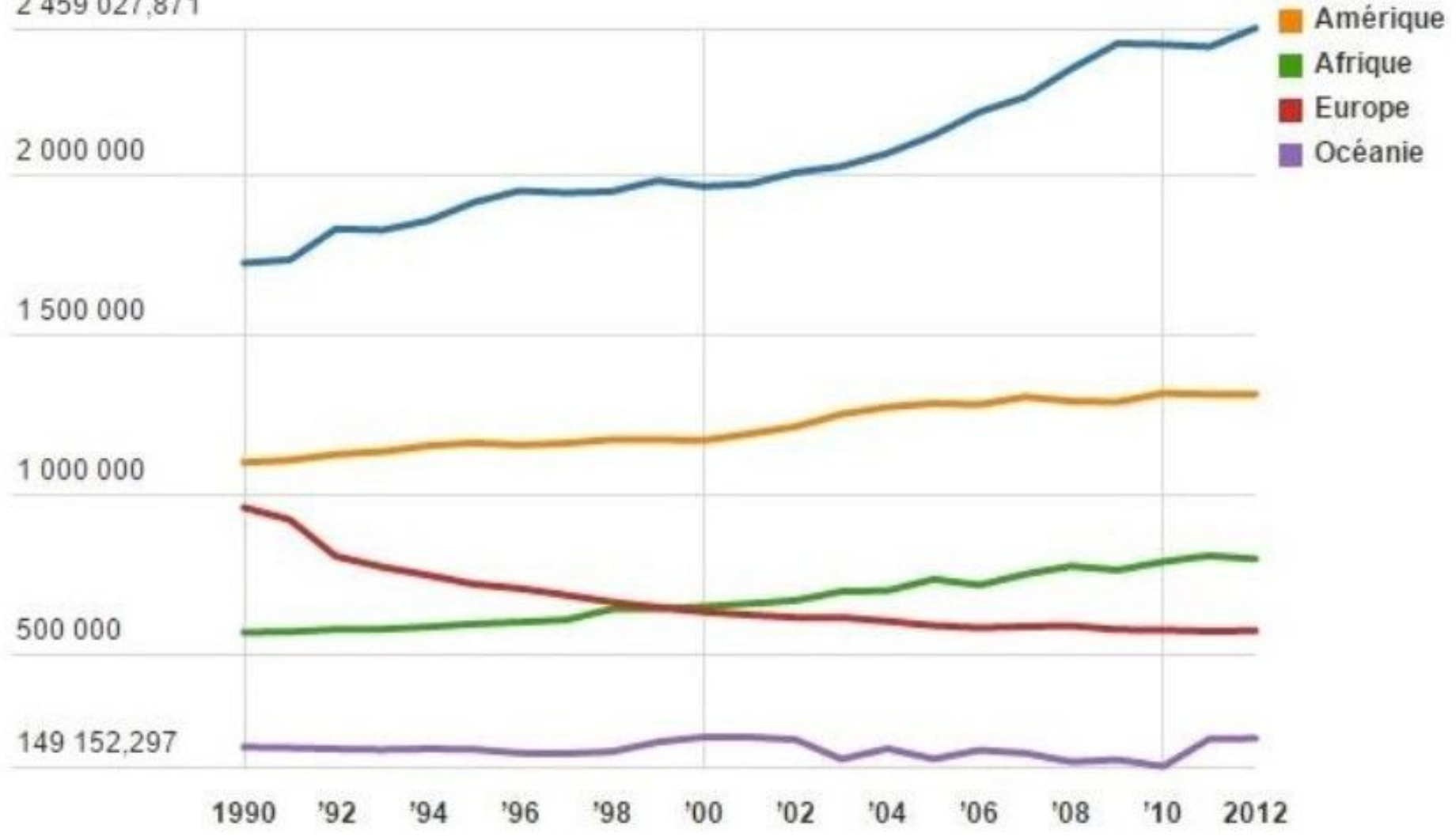

D’après http://www.reporterre.net/Climat-l-agriculture-est-la-source

Figure 2

Representative slide from a student presentation about Agriculture and climate change. 


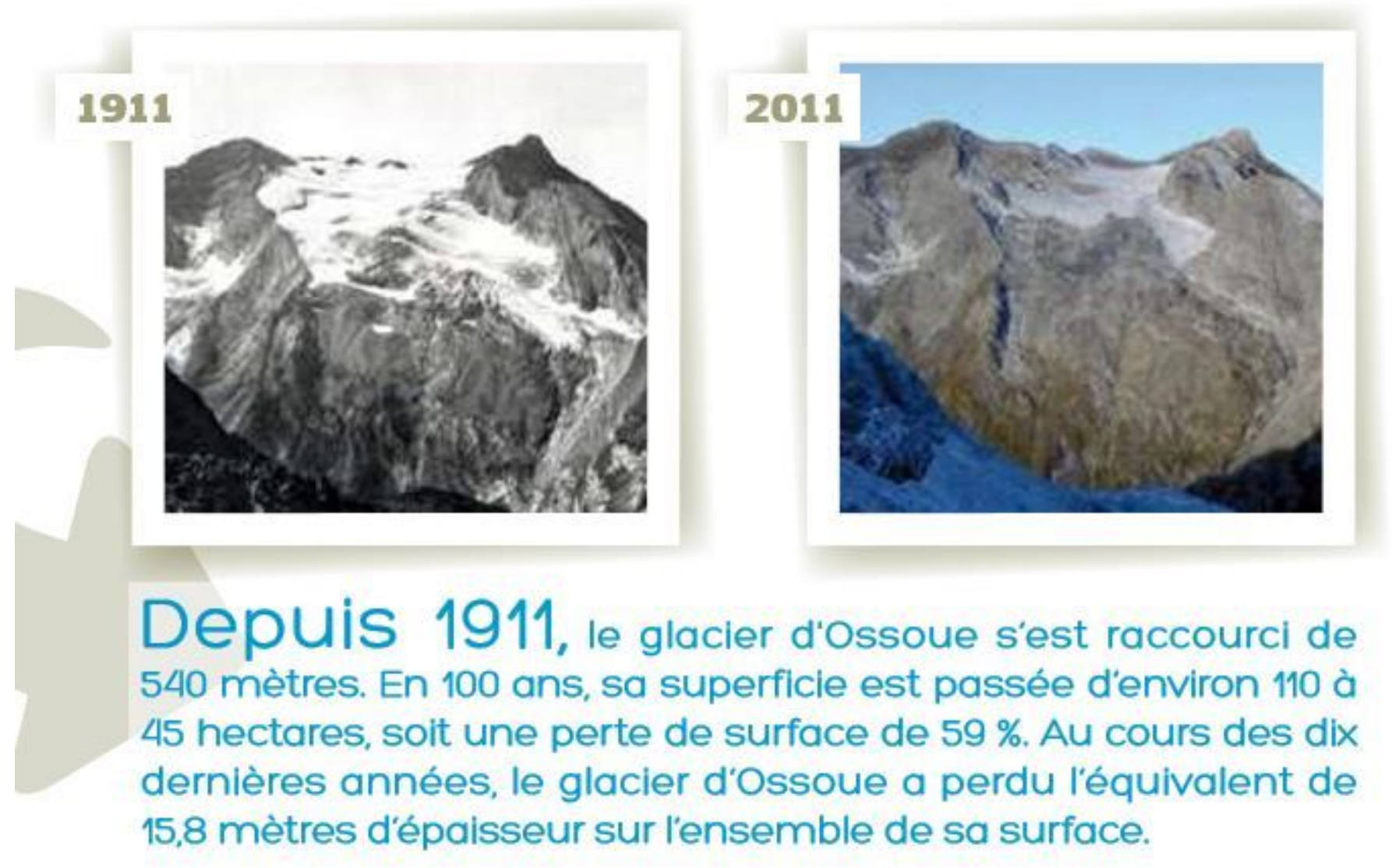

Figure 3

Representative slide from a student presentation about Water Resource Management and climate change. https.ecologie.gouv.fr/sites/default/files/ONERC_FichesIndicateur_glacier.pdf 
Évolution des zones adaptées à la viticulture en Europe d'ici à 2050, dans le cas du RCP8.5 du GIEC

\section{Situation actuelle}

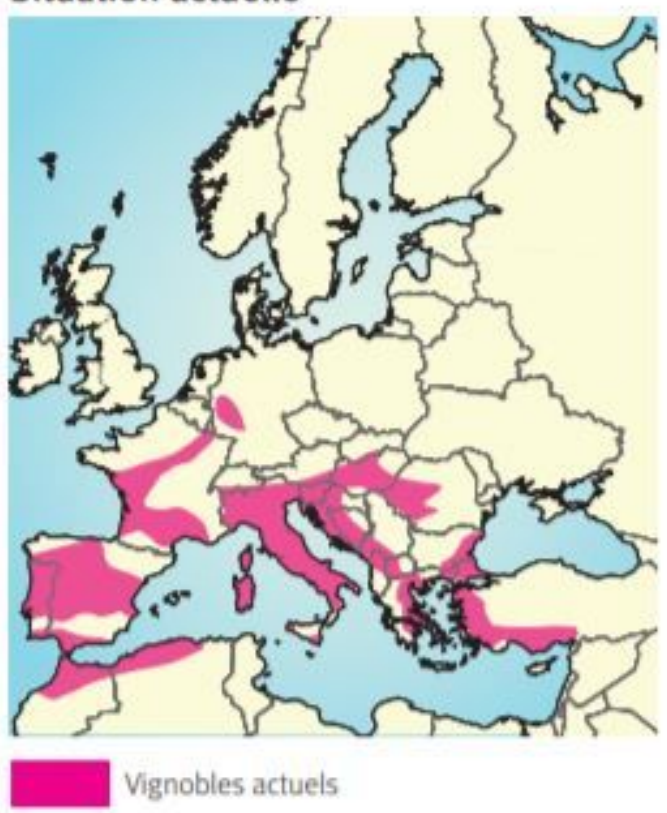

Prévisions pour 2050

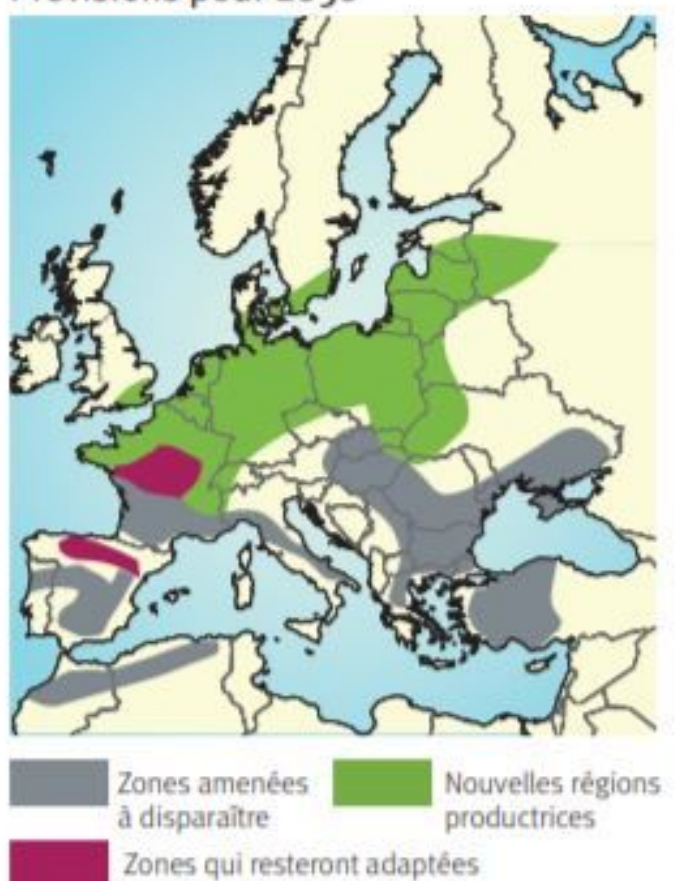

Source: Proceedings of the National Academy of Sciences of the United States of America.

\section{Figure 4}

Representative slide from student presentation about Biodiversity and climate change. Predicted distribution of vineyards under climate change scenario RCP 8.5

Tuvalu, archipel menace par la hausse du niveau des mers

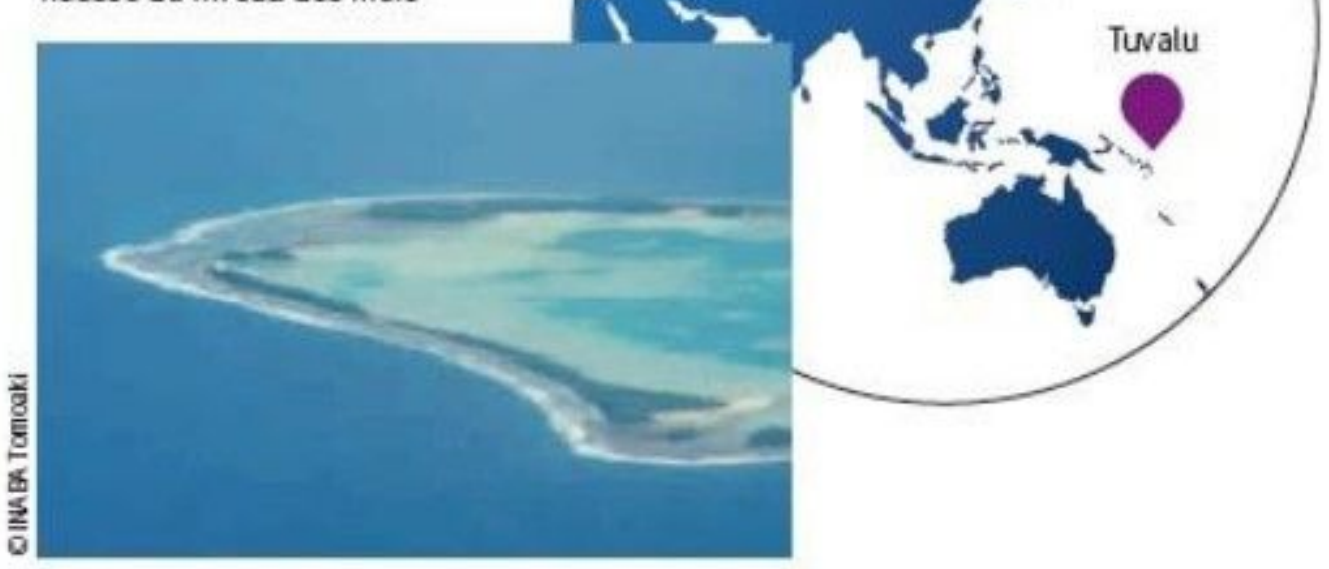




\section{Figure 5}

Representative slide from student presentation about Population Migrations and climate change. Source: Kit pédagogique le changement climatique p30 https://reseauactionclimat.org/publications/kitpedagogique-changements-climatiques/ (Publisher gives permission to use these in public education.)

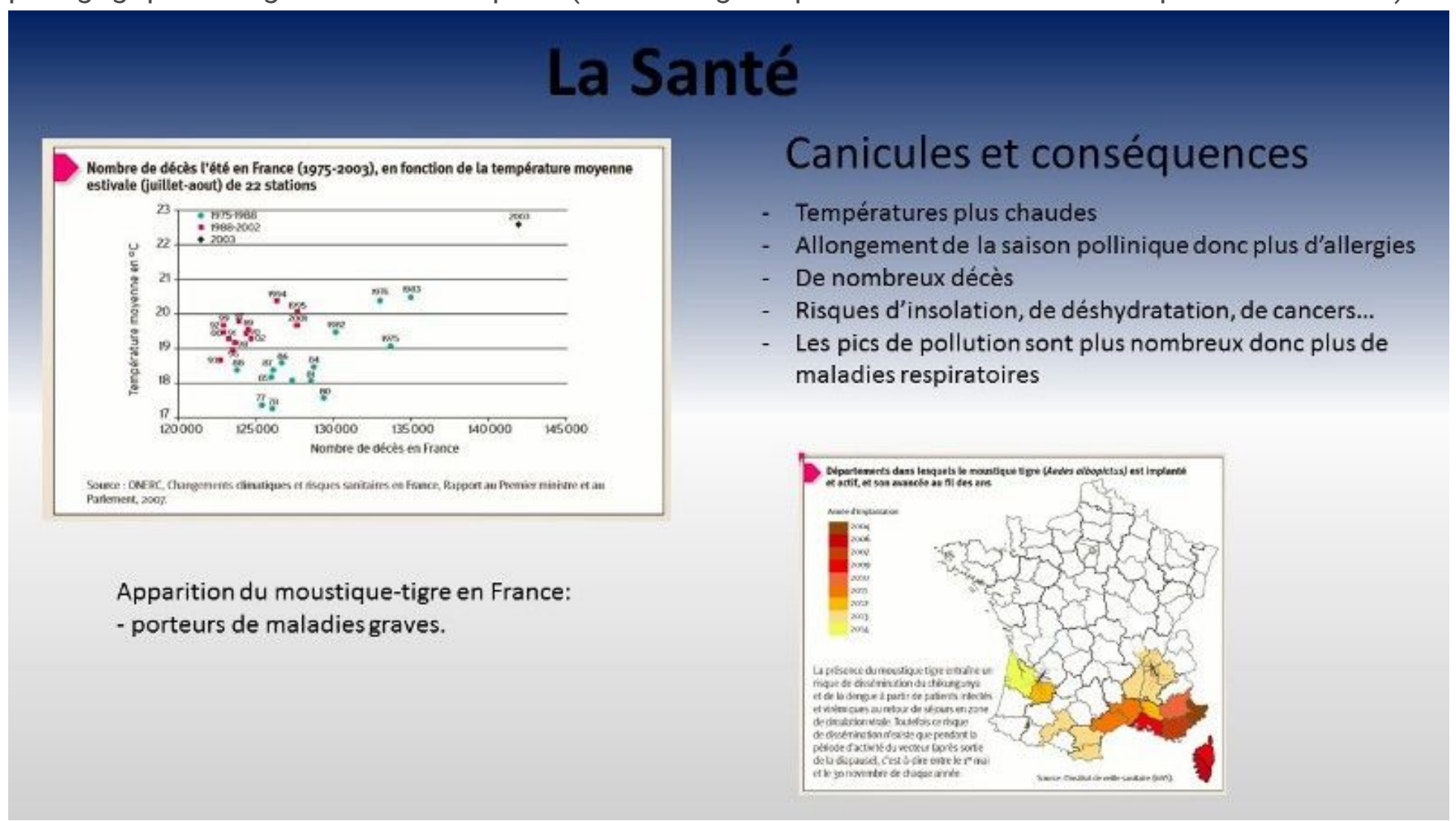

\section{Figure 6}

Representative slide from student presentation on Health and climate change. Source: Kit pédagogique le changement climatique p 40 https://reseauactionclimat.org/publications/kit-pedagogique-changementsclimatiques/ 


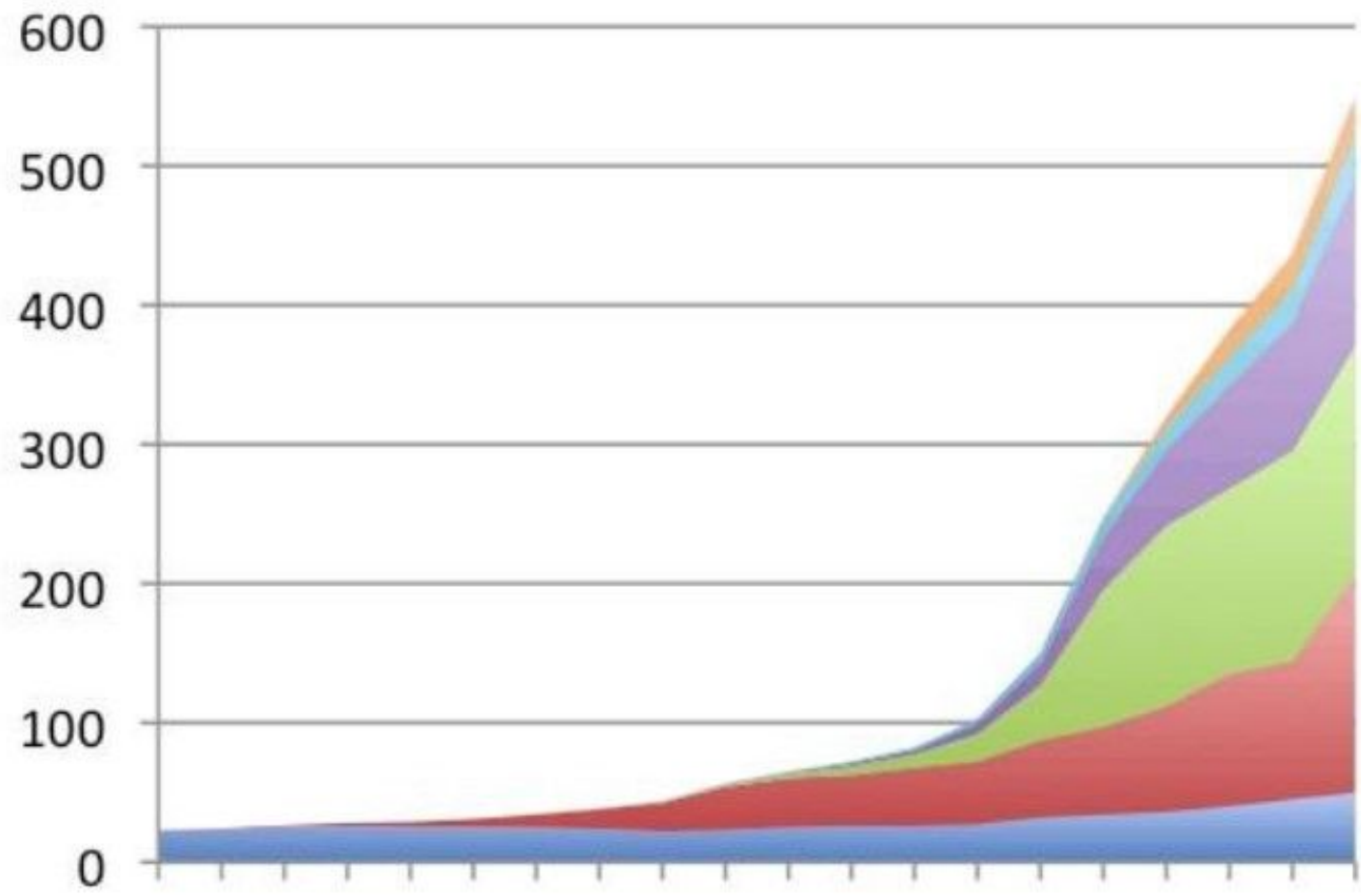

Nucléaire

Hydroélectricité

Gaz naturel

Pétrole

Charbon

Biomasse

\section{0}

Consommation énergétique mondiale en exajoules (EJ) par an

Source: Grubler A et al. (2012); Global Energy Assessment-Toward a Sustainable Future - IIASA

\section{Figure 7}

Representative slide from student presentation on Energy and climate change. Source: http://pure.iiasa.ac.at/id/eprint/10068/ used in accord with Creative Commons license. https://creativecommons.org/licenses/by/3.0/ 


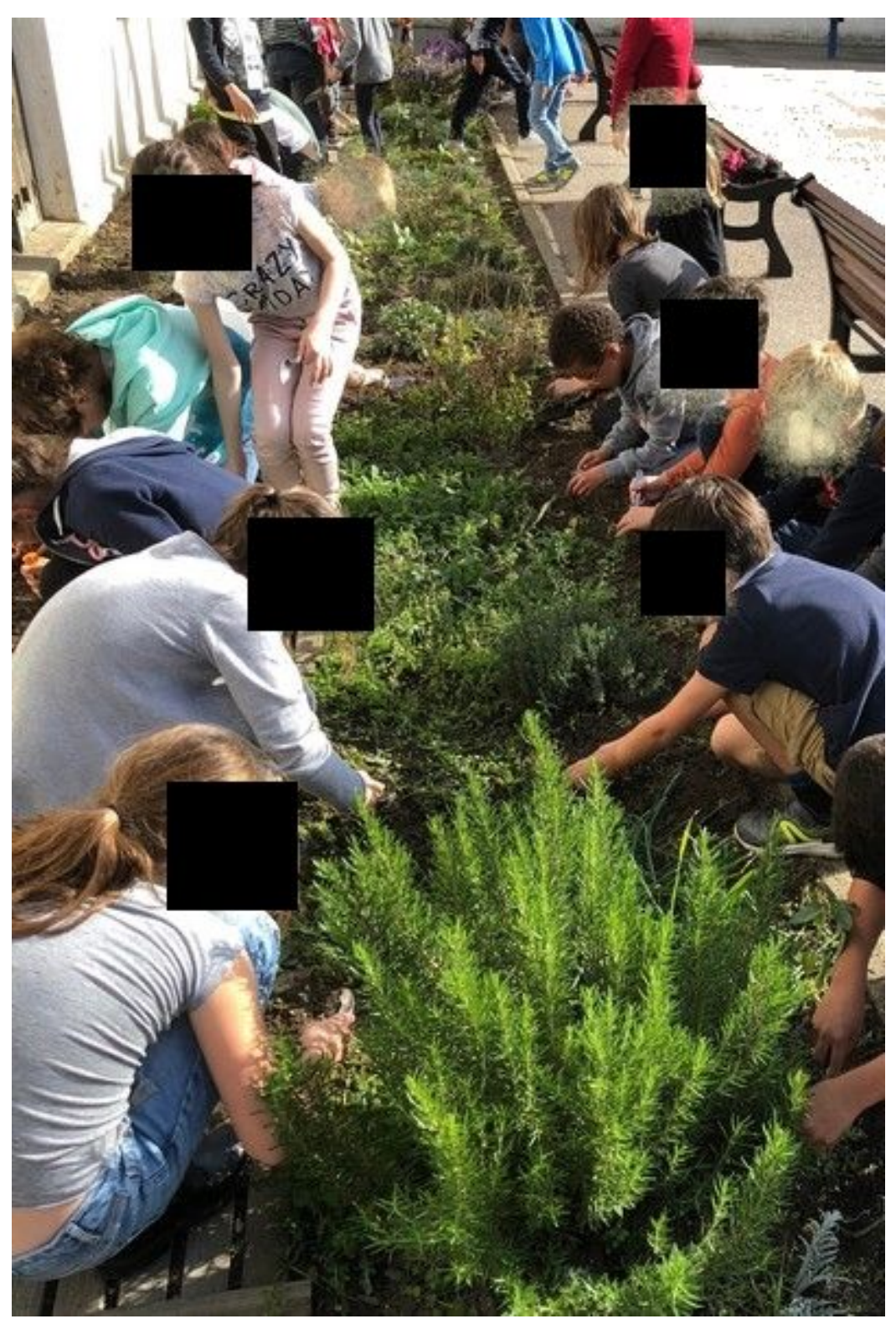

Figure 8

Pupils working in the pollinator garden. 


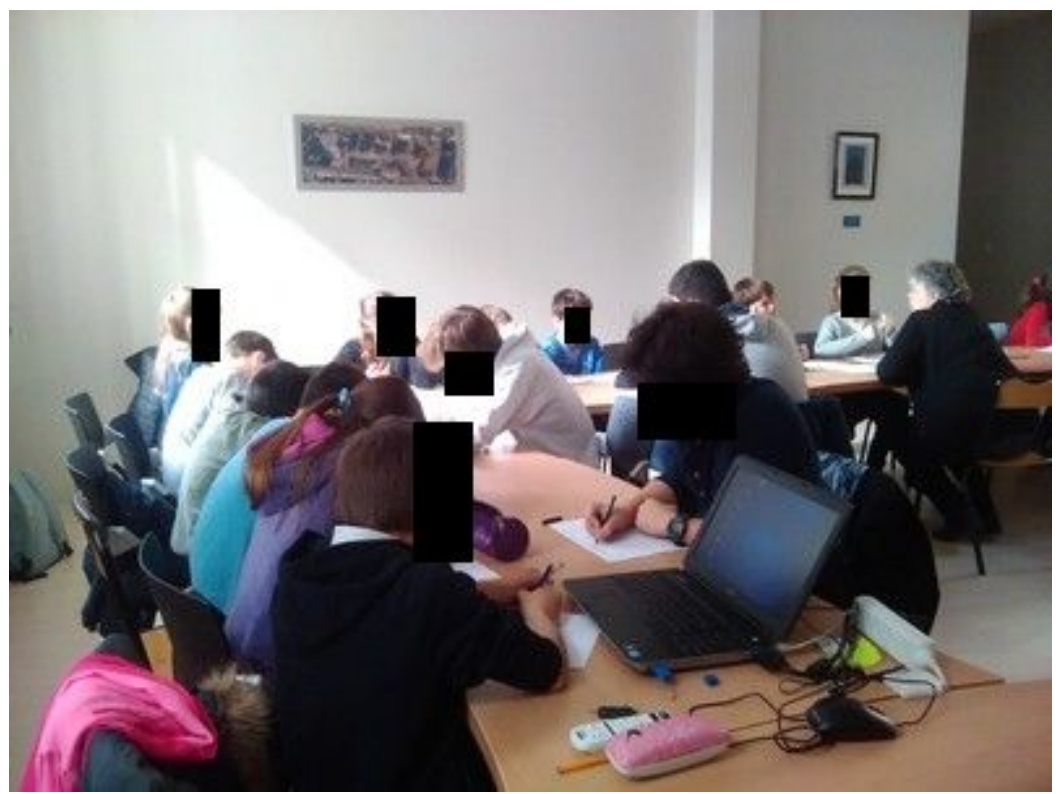

Figure 9

Pupils and students working together.

\section{Supplementary Files}

This is a list of supplementary files associated with this preprint. Click to download.

- File1RencontreavecMmeH.docx 